\title{
Perilaku Siswa Dalam Clique Perokok Elektrik Vaporizer di SMA Negeri 15 Padang
}

\author{
Atikah Zulfa ${ }^{1}$, Erianjoni Erianjoni ${ }^{2}$, Mohammad Isa Gautama ${ }^{3}$ \\ 1,2,3Universitas Negeri Padang
}

email: atikahzulfa01@gmail.com, erian joni@yahoo.com, migatama@fis.unp.ac.id.

\begin{abstract}
Abstrak
Penelitian ini mengkaji perilaku siswa dalam clique perokok elektrik vaporizer di SMA Negeri 15 Padang. Secara umum siswa pengguna rokok elektrik vaporizer menunjukkan perilaku yang berbeda dari siswa lainnya yang tidak merokok. Penelitian dilakukan dengan pendekatan kualitatif, jenis penelitian studi kasus. Teknik pemilihan informan dengan purposive sampling. Data dikumpulkan melalui observasi, wawancara mendalam, dan studi dokumen. Untuk mendapat keabsahan data dilakukan triangulasi sumber, teknik dan waktu. Data dianalisis dengan model interaktif dari Miles dan Huberman. Temuan penelitian ini adalah perilaku siswa dalam Clique perokok elektrik vaporizer di SMA Negeri 15 Padang: (1.) suka melokalisir diri untuk mencari tempat yang aman agar bisa merokok; (2.) eksklusif dalam memilih teman. Kecenderungan siswa perokok juga akan berteman dengan teman yang juga seorang perokok; (3.) suka berbohong. Mereka umumnya berbohong untuk melindungi diri agar tidak ketahuan merokok; (4.) kurang memiliki kepedulian sosial, karena mereka lebih memilih untuk merokok dari pada ikut dalam kegiatan sekolah seperti gotong-royong.
\end{abstract}

Kata Kunci: Perilaku, Clique, Rokok Elektrik Vaporizer

\begin{abstract}
Abstrack
This study examined the behavior of students in the electric smoker clique vaporizer in SMA Negeri 15 Padang. in general students using e-cigarettes, vaporizer exhibit different behavior from other students who do not smoke. The research was conducted with a qualitative approach, a type of case study research. The informant selection techniques is porposive sampling data is collected through observation exhaustive interview and document studies to get the validity of the data triangulation of sourzes, tecniques and time is carned out. The data were analyzed by interactive models from Miles and Huberman. The result of the study are: (1) the students like to localize themselves to tind a safe place to smoke (2) exclusive in choosing friends the tendency of smoker students will also be friends with someone who are also a smoker (3) they generally lie to protect themselves from being caught smoking (4) lack of social awareness they prefer to smoke rather than participate in school activities such as gotong royong.
\end{abstract}

Keywords:Behavior, Clique, Elektric Cigarethe Vaporizer 


\section{Pendahuluan}

Rokok elektrik vaporizer merupakan salah satu jenis rokok baru yang tengah menjadi fenomena baru dikalangan masyarakat Indonesia. Rokok elektrik dirancang untuk menghasilkan uap nikotin tanpa pembakaran tembakau dengan tetap memberikan sensasi merokok. Dibandingkan dengan rokok konvensional, rokok elektrik vaporizer atau yang dikenal dengan vape, menghasilkan asap yang lebih banyak. Hal tersebut membuat pemakainya bisa membuat variasi asap sedemikian rupa sesuai dengan yang diinginkannya. Namun dibandingkan dengan rokok konvensional, harga rakok vape ini memang lebih mahal berkisar antara Rp 300.000 sampai dengan Rp 1.000.000. Meski harganya tergolong mahal, namun banyak pecandu rokok yang tetap membelinya. Rokok elektrik saat ini sangat mudah ditemui baik secara online maupun di tempat-tempat khusus yang memang menjual rokok elektrik vaporizer ini.

Rokok elektrik ini tidak hanya diminati oleh perokok dewasa, namun juga menjadi tren di kalangan remaja tidak terkecuali di kalangan para pelajar di Indonesia. Fenomena menggunakan rokok elektrik vaporizer ini juga terjadi pada kalangan pelajar di Kota Padang tepatnya yaitu siswa di SMA Negeri 15 Padang. Selain menghisap rokok konvensional, siswa di SMA Negeri 15 Padang juga banyak yang sudah menjadi pecandu rokok vape ini. Tidak hanya di luar sekolah, namun para siswa juga banyak yang menggunakan rokok vape ini di kawasan lingkungan sekolah. Padahal sudah ada aturan yang melarang merokok di sekolah. Larangan merokok di SMA Negeri 15 Padang dibuat dalam bentuk spanduk-spanduk yang dipajang di depan ruangan kelas. Secara formal adanya larangan merokok di kawasan lingkungan sekolah juga dituangkan pemerintah dalam peraturan Menteri Pendidikan dan Kebudayaan Republik Indonesia nomor 64 tahun 2015. Sasaran kawasan tanpa rokok di lingkungan sekolah dalam pasal 3 yakni mencakup kepala sekolah, guru, tenaga pendidik dan kependidikan serta pihak lain dalam lingkungan sekolah.

Meskipun sudah adanya larangan merokok di kawasan lingkungan sekolah, namun tetap banyak para siswa yang menggunakannya. Tidak hanya secara individu, namun para siswa menggunakannya secara berkelompok dengan teman-teman atau kelompok clique-nya. Para siswa biasanya menggunakan rokok vape tersebut saat berkumpul bersama teman-temannya. Kebiasaan merokok ini berawal dari coba-coba dan akhirnya menjadi kecanduan. Para siswa yang sudah menjadi pecandu rokok, umumnya akan berpengaruh terhadap terjadinya perubahan perilaku pada individu bersangkutan.

Beberapa studi relevan terkait penelitian ini adalah pertama oleh (Apsari Damayanti, 2016) mengenai penggunaan rokok elektronik di komunitas personal vaporizer di Surabaya. Hasilnya menunjukkan alasan menggunakan rokok elektrik sebagai alternatif untuk berhenti merokok. Pengetahuan yang baik tentang rokok elektrik vaporizer, merupakan faktor protektif menjadi pengguna rokok elektrik tingkat berat. Penelitian dari (Delima Rahayu Istiqomah, 2016) mengenai gaya hidup komunitas rokok elektrik Semarang vape corner. Hasil penelitian menunjukkan bahwa berdasarkan faktor enabling sebagian besar responden memiliki kemudahan akses untuk membeli rokok elektrik. Berdasarkan faktor reinforcing sebagian besar responden kurang memiliki dukungan dari keluarga untuk menggunakan rokok elektrik yaitu sebesar 52,2\%, namun mendapat dukungan dari kelompok referensi sebesar 66,7\%. Penelitian dari Indri Kemala Nasution tentang perilaku merokok pada remaja menunjukkan bahwa ada beberapa faktor dan motif perokok diantara faktor psikologis dan juga mengurangi stres. Jumlah rokok yang dikonsumsi berkaitan dengan stres yang dialami, semakin besar stres yang dialami remaja semakin banyak pula rokok yang mereka konsumsi. 
Berbeda dari penelitian di atas, dalam penelitian ini lebih fokus untuk melihat perilaku remaja usia sekolah dalam clique perokok elektrik. Remaja pada tiap kelompok memiliki pola perilaku yang berbeda-beda termasuk pada siswa SMA Negeri 15 Padang. Hal ini terjadi karena pada usia remaja mereka cenderung berusaha untuk menunjukkan identitas diri, dan cenderung ingin berbeda dari yang lain. Berdasarkan hal tersebut, maka yang menjadi pertanyaan dalam penelitian ini adalah: bagaimana perilaku siswa dalam clique perokok elektrik vaporizer di SMA Negeri 15 Padang di luar jam belajar. Penelitian ini bertujuan untuk menjelaskan perilaku siswa dalam clique perokok elektrik vaporizer di SMA Negeri 15 Padang di luar jam belajar.

Penelitian ini secara teoritis bermanfaat untuk memberikan pemahaman mengenai prilaku siswa perokok dalam clique di SMA Negeri 15 Padang di luar jam belajar. Secara praktis untuk memberikan wacana dan dapat dijadikan referensi untuk melakukan penelitian selanjutnya.

Penelitian ini dianalisis dengan teori perubahan perilaku yang dikemukakan oleh Kurt Lewin. Kurt Lewin berpendapat bahwa perilaku manusia adalah suatu keadaan yang seimbang antara kekuatan-kekuatan pendorong (driving forces) dan kekuatan-kekuatan penahan (restining forces). Perilaku itu dapat berubah apabila kekuatan-kekuatan dalam diri tersebut memiliki ketidakseimbangan di dalam diri seseorang maka ada tiga terjadinya perubahan perilaku. Kekuatan-kekuatan pendorong meningkat sehingga akan terjadinya pendorong untuk perubahan perilaku. Stimulus ini berupa penyuluhan atau informasi yang diberikan. Kekuatankekuatan penahan melemah sehingga akan menurunkan kekuatan penahan. Kekuatan pendorong meningkat kekuatan penahan menurun.

Kurt Lewin (1951) juga merumuskan satu model hubungan perilaku yang mengatakan bahwa perilaku (B) adalah fungsi karakteristik individu (P) dan lingkungan (E), dengan rumus: $B=f(P, E)$. Karakteristik individu meliputi berbagai variabel seperti motif, nilai-nilai, sifat kepribadian, dan sikap yang saling berinteraksi satu sama lain dan kemudian berinteraksi pula dengan faktor-faktor lingkungan dalam menentukan perilaku. Bahkan kadang-kadang kekuatannya lebih besar dari pada karakteristik individu.

Siswa yang merokok cenderung memiliki perilaku yang berbeda dengan siswa umumnya yang tidak merokok. Begitupun halnya dalam kelompok pertemanan atau clique pada siswa di SMA Negeri 15 Padang. Antara satu clique dengan clique yang lain cenderung mempunyai perilaku yang berbeda-beda dan memiliki ciri khas masing-masing. Hal ini dapat terjadi karena tiap clique mempunyai faktor yang berbeda dalam mempengaruhi setiap perilaku anggota dalam clique nya. Masing-masing anggota clique cenderung menunjukan perbedaan perilaku dengan anggota kelompok clique yang lainnya. Hal ini bisa terjadi karena masing-masing clique memiliki kekuatan penahan dan pendorong yang berbeda-beda. Lewin juga berpendapat bahwa perubahan perilaku bisa juga terjadi karena lingkungan. Menurut Lewin hal ini bisa terjadi ketika pengaruh lingkungan lebih kuat dari karakteristik individu.

\section{Metode Penelitian}

Pendekatan dalam penelitian ini adalah kualitatif, yaitu suatu pendekatan yang menjelaskan realitas sosial yang diteliti secara mendalam. Jenis penelitiannya adalah studi kasus yaitu menelaah mengenai suatu keadaan masyarakat yang dilihat dari persoalan atau kasus tertentu, baik dalam suatu lembaga, kelompok maupun individu. Teknik pemilihan informan dengan purposive sampling, dengan informan penelitian berjumlah 21 orang, diantaranya; siswa SMA Negeri 15 Padang yang menjadi pengguna rokok elektrik vaporizer, guru SMA Negeri 15 Padang, orangtua siswa, serta penjual rokok elektrik vaporizer.

Teknik pengumpulan data dilakukan melalui observasi, wawancara mendalam, dan studi dokumen. Pengamatan dilakukan terhadap tindakan yang dilakukan oleh para siswa yang 
menjadi pengguna rokok elektrik vaporizer di SMA Negeri 15 Padang. Kemudian melakukan wawancara mendalam kepada siswa tersebut, serta dokumen yang membantu penulis untuk mendapatkan informasi penelitian.

Untuk mendapat keabsahan data dilakukan triangulasi. Data yang sama dikumpulkan dari objek yang berbeda. Triangulasi yang digunakan yaitu triangulasi sumber, teknik dan waktu. Dalam melakukan analisis data penulis menggunakan model analisis interaktif dari Miles dan Huberman melalui tiga langkah yang dilakukan secara berkesinambungan selama proses penelitian yaitu reduksi data, penyajian data, dan penarikan kesimpulan.

\section{Hasil dan Pembahasan}

Rokok elektrik vaporizer menjadi tren baru bagi siswa di SMA Negeri 15 Padang. Tidak hanya menggunakannya di luar kawasan lingkungan sekolah, namun ada juga dari mereka yang justru menggunakannya di pekarangan sekolah. Hal tersebut tentu akan menjadi masalah, karena sudah ada aturan sekolah yang melarang menggunakan rokok di kawasan lingkungan sekolah. Lingkungan sekolah seharusnya menjadi kawasan bebas asap rokok, namun sekarang sudah tercemar oleh asap rokok. Tidak hanya rokok konvensional, namun rokok elektrik atau yang lebih dikenal dengan vape menjadi tren baru merokok bagi para siswa. Rokok vape ini memiliki asap yang lebih banyak jika dibandingkan dengan rokok konvensional. Harga rokok ini juga lebih mahal mencapai ratusan ribu dan ada yang sampai satu juta dibandingkan dengan rokok konvensional yang harganya hanya puluhan ribu.

Penggunaan rokok elektrik vaporizer ini sangat berpengaruh terhadap perilaku para penggunanya. Begitupun halnya pada siswa di SMA Negeri 15 Padang. Tidak hanya secara individu, namun mereka ada yang menggunaknnya dalam kelompok bersama dengan temantemannya atau clique. Beberapa perilaku siswa perokok elektrik vaporizer dalam clique siswa di SMA Negeri 15 Padang di luar jam belajar adalah sebagai berikut:

Pertama, melokalisir diri. Perilaku melokalisir diri termasuk ke dalam salah satu perilaku yang ditunjukkan oleh para siswa terutama bagi mereka para pengguna rokok elektrik vaporizer di SMA Negeri 15 Padang. Perilaku melokalisir diri ini dapat dikategorikan bahwa siswa tersebut lebih suka menyendiri di tempat-tempat khusus dan umumnya bersifat lebih tertutup. Siswa yang menjadi pengguna rokok elektrik vaporizer ini memiliki kecenderungan untuk melokalisir diri atau mencari tempat-tempat yang khusus karena adanya aturan sekolah yang melarang mereka untuk merokok di kawasan lingkungan sekolah.

Tempat-tempat yang pada umumnya mereka gunakan untuk merokok adalah a.) kantin. Kantin merupakan suatu tempat yang dianggap paling strategis untuk bisa merokok bagi para siswa. Para siswa umumnya lebih memilih kantin untuk menghisap rokok dikarenakan tempat ini tertutup sehingga membuat para siswa menjadi merasa aman tanpa takut ketahuan oleh guru saat mereka merokok di kantin; b.) Toilet atau WC sekolah. Toilet juga dimanfaatkan para siswa sebagai tempat yang aman untuk merokok. Tempatnya yang tertutup memungkinkan para siswa untuk lebih leluasa bisa merokok. Sehingga tidak jarang toilet banyak dipenuhi dengan sampah puntung rokok yang bertebaran dimana-mana, terutama di WC laki-laki. Tidak hanya menggunakan rokok konvensional, para siswa di SMAN 15 Padang juga ada yang menggunakan rokok elektrik vaporizer di toilet atau WC sekolah; c.) Kos-kosan merupakan suatu tempat yang juga aman bagi para siswa untuk bisa merokok. Tempat yang terturu serta tidak ada larangan untuk merokok di kawasan tersebut. Tidak hanya anak kuliahan, para siswa juga ada sebagain yang tinggal di kos-kosan.

Berdasarkan penjelasan di atas dapat diketahui bahwa para siswa pengguna rokok elektrik vaporizer cenderung lebih suka mencari tempat-tempat khusus atau melokalisir diri 
agar bisa merokok. Tempat-tempat yang mereka pilih untuk nongkrong agar diantaranya adalah kantin sekolah, toilet atau WC sekolah dan di kos-kosan.

Uraian di atas sesuai dengan yang diungkapkan Kurt Lewin dalam teori perubahan perilakunya yang menyatakan bahwa perilaku pada diri seseorang dapat berubah apabila tidak adanya keseimbangan dalam dirinya. Hal tersebut berkaitan dengan terjadinya perubahan sikap pada diri siswa para pengguna rokok elektrik vaporizer ini. Tidak adanya keseimbangan dalam diri seorang siswa membuatnya menjadi terpengaruh untuk menggunakan rokok elektrik vaporizer. Mereka yang sudah menjadi pecandu rokok, jika tetap ingin merokok di kawasan lingkungan sekolah harus mencari tempat-tempat yang sepi agar bisa aman merokok. Hal inilah yang menjadi pendorong utama para siswa pecandu rokok menjadi suka melokalisir diri. Kuatnya dorongan dalam diri untuk merokok, sementara mereka juga harus mencari tempat yang aman untuk merokok mendorong terjadinya perubahan perilaku pada siswa. Perubahan perilaku yang dapat terlihat adalah umumnya para siswa cenderung lebih bersifat tertutup dan suka menyendiri.

Kedua, selektif memilih teman. Pengguna rokok elektrik vaporizer ini memang selektif dalam memilih teman. Hal ini disebabkan karena adanya faktor ekonomi dari masing-masing siswa tersebut. Hal ini terjadi karena masing-masing kelompok atau clique tersebut melihat vape dari segi kualitasnya. Semakin tinggi harga vape berarti maka akan semakin mahal harganya, begitu juga dengan kelompok atau clique yang menggunakannya. Selain dapat dilihat dari kualitas vape yang mereka gunakan, para siswa dalam tiap-tiap clique juga memiliki tempat nongkrong, gaya berpakaian, serta alat yang digunakan untuk mengambil gambar/fhoto.

Berdasarkan hal tersebut dapat disimpulkan bahwa siswa di SMA Negeri 15 Padang yang menjadi pengguna rokok elektrik vaporizer cenderung selektif memilih teman. Hal ini juga disebabkan karena pada umumya mereka dalam satu clique tertentu mempunyai kebiasaan dan identitas yang menjadi ciri khas clique mereka. Sehingga mereka akan cenderung sulit untuk menerima orang baru diluar clique, apalagi jika orang tersebut tidak sesuai dengan kriteria clique mereka.

Fenomena yang pada umumnya terjadi adalah seorang perokok juga akan bergaul dengan mereka yang juga perokok. Hal inilah yang menyebabkan mereka menjadi selektif memilih teman. Karakteristik individu yang berbeda-beda bisa disatukan ketika mereka sudah samasama menjadi pecandu rokok elektrik vaporizer ini. Ditambah dengan adanya dorongan yang kuat dari lingkungan yang pada akhirnya membuat mereka menjadi pecandu rokok elektrik ini.

Hal ini sesuai dengan yang dijelaskan Kurt Lewin (1951) dalam model perilakunya dengan rumus $\mathrm{B}=\mathrm{f}(\mathrm{P}, \mathrm{E})$. $\mathrm{B}$ yang menunjukkan perilaku, $\mathrm{P}$ adalah kepribadian, $\mathrm{E}$ adalah lingkungan dan $\mathrm{f}$ adalah fungsi. Dari formula tersebut diinterpretasikan bahwa kepribadian seseorang merupakan unsur penting pembentuk perilaku. Para siswa yang sudah menjadi pecandu rokok menunjukkan terjadinya perubahan perilaku karena mereka menjadi lebih selektif dalam memilih teman, hal itu tidak terlepas karena adanya dorongan dari lingkungannya sesama perokok. Jika mereka bergaul dengan sesama teman yang merokok, maka mereka bisa lebih puas merokok. Berbeda dengan mereka yang bukan perokok, karena bisa saja jika mereka terlalu akrab bergaul dengan teman yang bukan pecandu rokok maka mereka berada dalam bahaya. Hal ini terjadi karena bisa jadi mereka yang bukan perokok akan mengadukan perbuatan mereka pada orangtua, guru-guru maupun pihak sekolah lainnya yang bisa membuat mereka mendapatkan sanksi karena adanya larangan untuk merokok di kawasan lingkungan sekolah.

Ketiga, suka berbohong. Kebiasaan berbohong ini terjadi karena para siswa yang merokok umumnya selalu mengelak apabila dilakukan razia. Siswa yang ketahuan membawa rokok ataupun ketahuan menghisap rokok umumnya tidak mengakui atau jujur dengan perbuatan yang sudah dilakukannya. bahwa para siswa yang menjadi pengguna rokok elektrik 
vaporizer sering berbohong baik kepada orangtua di rumah maupun kepada guru saat berada di sekolah. Cara yang mereka gunakan yaitu dengan meminta uang untuk membeli buku kepada orangtua, padahal mereka menggunakannya untuk membeli vape. Begitu juga pada saat di sekolah, hal ini umumnya mereka lakukan untuk melindungi diri mereka agar tidak dimarahi maupun dihukum.

Berbohong mereka lakukan karena adanya tekanan dari dalam maupun dari luar diri mereka. Mereka menginginkan vape, sementara tidak memiliki uang untuk membelinya. Pada akhirnya jalan yang mereka tempuh adalah dengan membohongi orangtua. Umumnya mereka akan meminta uang untuk jajan atau belanja maupun untuk membeli buku-buku di sekolah, padahal sebenarnya uang tersebut mereka pergunakan untuk membeli rokok elektrik vaporizer atau yang mereka sebut vape. Adanya dorongan tersebutlah yang pada akhirnya menjadi penyebab siswa mempunyai kebiasaan berbohong.

Selain hal tersebut, kasus lain dapat dilihat pada saat dilakukan razia oleh guru. Untuk melindungi dirinya tak jarang siswa juga akan berbohong dengan mengelak bahwa ia sudah merokok di sekolah. Hal-hal tersebutlah yang menjadi penyebab para siswa pecandu rokok mempunyai perilaku suka berbohong. Lemahnya pertahanan diri sementara lingkungan luar menuntutnya harus berbohong agar tidak ketahuan bahwa mereka sudah merokok.

Hal tersebut juga sesuai dengan yang dijelaskan oleh Kurt Lewin dalam model perilakunya dengan rumus $\mathrm{B}=\mathrm{f}(\mathrm{P}, \mathrm{E})$. $\mathrm{B}$ menunjukkan perilaku, $\mathrm{P}$ kepribadian , $\mathrm{E}$ lingkungan dan $\mathrm{f}$ adalah fungsi. Perubahan perilaku dapat terjadi pada diri seorang individu ketika lemahnya pertahanan dalam diri, sementara itu ada dorongan yang kuat dari luar diri yang berasal dari faktor lingkungan sekitar. Pada saat mereka memilih untuk berbohong, berarti pertahanan dalam diri untuk berkata jujur dikalahkan oleh kuatnya dorongan dari luar untuk menutupi rasa bersalah karena sudah menggunakan rokok. Bahkan tidak jarang, mereka juga berbohong kepada guru untuk melindungi temannya agar tidak mendapatkan sanksi dari guru karena sudah menggunakan rokok.

Keempat, kurang memiliki kepedulian sosial. para siswa yang menjadi pecandu rokok membuatnya jadi kurang mempunyai rasa kepedulian terhadap sesama dan juga lingkungan sekitarnya. Perilaku ini juga terdapat pada clique siswa pengguna rokok elektrik vaporizer di SMA Negeri 15 Padang. Hal ini menyebabkan mereka menjadi punya sifat anti sosial. Hal tersebut dapat diketahui dari sikap yang mereka tunjukkan pada saat diadakannya kegiatankegiatan sekolah seperti gotong royong membersihkan kelas maupun lingkungan sekolah dan juga kegiatan-kegiatan sosial lainnya. Para siswa yang menjadi pecandu rokok umumnya lebih memilih untuk menongkrong di kantin maupun di tempat-tempat lainnya agar mereka tidak terlibat dalam kegiatan-kegiatan sekolah sepertinya halnya gotong royong, class meeting dan lainnya.

Indikator lain yang menunjukkan perilaku anti sosial lainnya yaitu pada saat terjadinya musibah. Jika anggota dari clique mereka yang mendapat musibah atau sedang sakit maka mereka umumnya akan lebih peduli . Berbeda jika orang tersebut berasal dari luar anggota clique mereka, kecenderungan mereka tidak atau kurang peduli satu sama lain karena bukan bagian dari anggota clique mereka. Kecenderungan para siswa yang sudah menjadi pecandu rokok akan punya sifat mengarah pada antisosial karena mereka menghabiskan banyak waktu mereka untuk aktivitas bersama dengan teman-teman kelompoknya untuk merokok bersama, dibandingkan melakukan aktivitas lainnya yang sifatnya untuk kepentingan bersama.

Pada saat melakukan hal demikian sebenarnya mereka juga dihadapkan dengan dua pilihan yakni memilih ikut nongkrong dengan teman-temannya atau mengikuti kegiatankegiatan sekolah seperti gotong royong, class meeting dan lainnya. Hal ini juga sesuai dengan pernyataan Kurt Lewin yang menyatakan bahwa perubahan perilaku dapat terjadi ketika kekuatan pendorong meningkat sementara kekuatan penahannya melemah atau menurun. 
Ketika siswa di SMA Negeri 15 Padang lebih banyak yang memilih untuk ikut nongkrong dan merokok bersama teman-temannya, hal tersebut menunjukkan bahwa kekuatan pendorong yang datang dari luar lebih kuat dari pada faktor penahan dari dalam diri. Hal itulah yang pada akhirnya membuat para siswa pecandu rokok elektrik vaporizer di SMA Negeri 15 Padang menjadi kurang memiliki kepedulian sosial.

\section{Kesimpulan}

Rokok elektrik vaporizer sudah menjadi tren merokok baru di kalangan para siswa di SMA Negeri 15 Padang. Rokok jenis ini tidak hanya digunakan di luar lingkungan sekolah, namun mereka juga menggunakannya di dalam kawasan lingkungan sekolah. Padahal sudah ada aturan yang melarang merokok di kawasan lingkungan sekolah. Hal ini berdampak negatif, karena menyebabkan terjadinya perubahan perilaku pada siswa penggunanya. Siswa perokok umumnya menunjukkan perilaku yang berbeda dibandingkan dengan para siswa yang tidak merokok. Perilaku yang mereka tunjukkan cenderung negatif. Hal ini sesuai dengan yang diutarakan Kurt Lewin dalam model perilakunya dengan rumus $B=f(P, E)$. B yang menunjukkan perilaku, $\mathrm{P}$ adalah kepribadian, $\mathrm{E}$ adalah lingkungan dan $\mathrm{f}$ adalah fungsi. Dari formula tersebut diinterpretasikan bahwa kepribadian seseorang merupakan unsur penting pembentuk perilaku.

Pertama, siswa suka melokalisir diri. Hal ini mereka lakukan karena adanya aturan sekolah yang melarang untuk merokok. Ketika mereka tetap ingin merokok, maka mereka harus mencari tempat-tempat khusus yang aman bagi mereka. Kawasan strategis yang dijadikan tempat merokok di antaranya adalah kantin, wc/toilet sekolah, dan di kos-kosan. Tempat ini dipilih karena tertutup sehingga mereka bisa bebas untuk merokok.

Kedua, eksklusif memilih teman. Para siswa pecandu rokok cenderung akan bergaul dengan teman yang juga perokok. Walaupun di dalam kelas mereka akan kompak, namun ketika menongkrong umumnya mereka akan akrab dengan sesama perokok. Hal inilah yang membuat perokok umumnya eksklusif dalam memilih teman. Jika mereka terlalu akrab dengan teman yang tidak merokok, maka ada kemungkinan perbuatan mereka tersebut akan dilaporkan kepada orangtua, guru dan pihak sekolah lainnya.

Ketiga, suka berbohong. Dalam hal ini seorang perokok dihadapkan dengan dua pilhan. Ketika mereka jujur, maka mereka akan mendapatkan sanksi karena sudah merokok. Disisi lain juga adanya tuntutan dari teman-teman sesama perokok. Perubahan perilaku dapat terjadi ketika pertahanan dalam diri untuk berkata jujur dikalahkan oleh kuatnya dorongan dari luar untuk menutupi rasa bersalah karena sudah menggunakan rokok.

Keempat, kurang memiliki kepedulian sosial. Hal ini terlihat pada saat dilaksanakannya kegiatan-kegiatan sekolah seperti gotong-royong, class meeting dan lainnya. Kecenderungan para siswa yang sudah menjadi pecandu rokok akan punya sifat mengarah pada antisosial karena mereka menghabiskan banyak waktu mereka untuk aktivitas bersama dengan temanteman kelompoknya untuk merokok bersama, dibandingkan melakukan aktivitas lainnya yang sifatnya untuk kepentingan bersama.

\section{Daftar Pustaka}

Damayanti, Absari. (2016). Penggunaan Rokok Elektronik di Komunitas Personal Vaporizer di Surabaya. Jurnal Departemen Epidemiologi Fakultas Kesehatan Masyarakat Universitas Airlangga Surabaya Jawa Timur Indonesia. https://media.neliti.com. Diakses tanggal 09 Mei 2018 pukul 16.52 WIB.

Erianjoni. (2014). Pelabelan Etnis Minangkabau Pada Wanita Pelaku Penyimpangan Sosial di Kota Padang.kafaah journal Of Gender Studies jilid 4 terbitan 1. Hal 124-140 
http://psmk.kemdikbud.go.id/konten/1609/aturan-dan-sanksi-kemdikbud-soal-merokokdi-sekolah. Diakses tanggal 12 Juli 2018 pukul 10.5 WIB.

M. Daud. (2015). Prediktor Perilaku Pemilih pada Pemilukada Perspektif Psikologi Politik. Vol 1, No 1, Talenta September 2015. Hal 86-87. Diakses pada tanggal 22 Agustus 2018 pada pukul 22.29 WIB.

Kemala Nasution, Indri. (2007). Perilaku Merokok Pada Remaja. Skripsi Program Studi Psikologi Fakultas Kedokteran Universitas Sumatera Utara. Diakses pada tanggal $10 \mathrm{Mei}$ 2018 Pukul 15.21 WIB. KTI Rizaluddin Akbar 2016. Repository.umy.ac.id. Diakses pada tanggal 26 mei 2018 pada pukul 12.06 WIB.

Rahayu Istiqomah, Delima. (2016). Gaya Hidup Komunitas Rokok Elektrik Semarang Vape Corner. Jurnal Kesehatan Masyarakat (e-journal) Volume 4, Nomor 2, April 2016 (ISSN:2356-3346) ictoh-tcscindonesia.com Diakses Tanggal 10 Mei 2018 Pukul 15.02 WIB.

Syani, Abdul. (2007). Sosiologi (Skematika, Teori, dan Terapan), PT. Bumi Aksara: Jakarta. 